This is the peer reviewed version of the following article:

Sannel, A.B.K., Hempel, L., Kessler, A. and Prèskienis, V., 2017: Holocene development and permafrost history in sub-arctic peatlands in Tavvavuoma, northern Sweden. Boreas 47, 454468, doi:10.1111/bor.12276, which has been published in final form at https://onlinelibrary.wiley.com/doi/abs/10.1111/bor.12276.

This article may be used for non-commercial purposes in accordance with Wiley Terms and Conditions for Use of Self-Archived Versions.

\title{
Holocene development and permafrost history in subarctic peatlands in Tavvavuoma, northern Sweden
}

\author{
A. Britta K. Sannel ${ }^{1}$, Liljen Hempel ${ }^{1}$, Alexander Kessler ${ }^{1}$ and Vilmantas Prèskienis ${ }^{1,2}$ \\ ${ }^{1}$ Department of Physical Geography, Stockholm University, 10691 Stockholm, Sweden \\ ${ }^{2}$ Eau-Terre-Environnement, Institut National de la Recherche Scientifique, Québec, \\ QC G1K 9A9, Canada
}

\begin{abstract}
Under changing climatic conditions permafrost peatlands can play an important role in the global carbon budget through permafrost carbon feedbacks and shifts in carbon assimilation. To better predict future dynamics in these ecosystems an increased understanding of their Holocene carbon and permafrost history is needed. In Tavvavuoma, northern Sweden, we have performed detailed analyses of vegetation succession and geochemical properties at six permafrost peatland sites. Peatland initiation took place around 10000 to $9600 \mathrm{cal}$. a BP, soon after deglaciation of the Fennoscandian Ice Sheet, and the peatlands have remained permafrost-free fens throughout most of the Holocene. At the four sites that showed a continuous accumulation record during the late Holocene radiocarbon dating of the shift from wet fen to dry bog vegetation, characteristic of the present permafrost peatland surface, suggests that permafrost developed around 600-100 cal. a BP. At the other two sites peat accumulation was halted during the late Holocene, possibly due to abrasion, making it more difficult to imply the timing of permafrost aggradation. However also at these sites there are no indications of permafrost inception prior to the Little Ice Age. The mean long-term Holocene carbon accumulation rate at all six sites was $12.3 \pm 2.4 \mathrm{gC} \mathrm{m}^{-2} \mathrm{a}^{-1}$ (standard deviation), and the mean soil organic carbon storage was $114 \pm 27 \mathrm{~kg} \mathrm{~m}^{-2}$.
\end{abstract}

\section{INTRODUCTION}

Northern peatlands cover vast areas and are important soil organic carbon reservoirs (Gorham 1991; Yu et al. 2010). Since their initiation, mainly during the early Holocene, these peatlands have acted as net carbon sinks through uptake of carbon dioxide $\left(\mathrm{CO}_{2}\right)$ and accumulation of only partly decomposed dead organic matter (MacDonald et al. 2006; Frolking \& Roulet 2007; Yu et al. 2009; Yu 2011; Loisel et al. 2014). Today boreal, subarctic and arctic peatlands in the northern circumpolar permafrost region cover around $2300000 \mathrm{~km}^{2}$ and store approximately $300 \mathrm{Pg} \mathrm{C}$ (Tarnocai et al. 2009; Hugelius et al. 2014). Long-term Holocene net carbon accumulation rates in these peatlands are typically around $14-23 \mathrm{gC} \mathrm{m}^{-2}$ $\mathrm{a}^{-1}$ (Treat et al. 2016). Under future warmer conditions, as predicted by e.g. Collins et al. (2013), permafrost peatlands can start to thaw, and these ecosystems can at least temporarily turn into carbon sources through increased emissions of $\mathrm{CO}_{2}$ from active-layer deepening and methane $\left(\mathrm{CH}_{4}\right)$ from intensified thermokarst processes (Tarnocai 2006; Schuur et al. 2008; Schuur et al.2015). Peatlands in the sporadic and discontinuous permafrost zones, which are 
already close to thawing, are most sensitive to changing climatic conditions (Tarnocai 2006; Parviainen \& Luoto 2007). In Fennoscandia peatlands cover approximately a quarter of the land surface (Parviainen \& Luoto 2007). Permafrost peatlands are found in lowland areas at high northern latitudes (north of $\sim 67^{\circ} \mathrm{N}$ ) in Sweden, Norway and Finland, but also at higher elevation in south-central Norway (Parviainen \& Luoto 2007; Backe 2014; Gisnås et al. 2017). In these regions palsas and peat plateaus are common landscape features.

After the retreat of the Fennoscandian Ice Sheet, the climate in subarctic Fennoscandia was relatively warm and moist (e.g. Seppä \& Birks 2001), promoting rapid initiation and lateral expansion of peatlands on newly exposed mineral soils (Weckström et al. 2010). Three different types of peat formation were common in the region during this time interval $(c$. 10 000-8 000 cal. a BP); primary mire formation directly on newly exposed mineral soil, terrestrialization through infilling of water bodies with organic matter and paludification following waterlogging of previously dry, vegetated land (Ruppel et al. 2013). Throughout most of the Holocene, these northern peatlands have not experienced climatic conditions cold enough for permafrost to form. The first period of permafrost aggradation in subarctic Fennoscandian peatlands is suggested to have occurred around 2600-2500 cal. a BP (Oksanen 2006; Kokfelt et al. 2010). However, most palsa mires and peat plateaus have a later Holocene origin, and were formed after 700 cal. a BP (Vorren 1979; Malmer \& Wallén 1996; Zuidhoff \& Kolstrup 2000; Seppälä 2005; Oksanen 2006; Kokfelt et al. 2010), as a result of climate cooling in the region around $850 \mathrm{cal}$. a BP and onset of the Little Ice Age (LIA) (Grudd et al. 2002; Bjune et al. 2009). Since there are no plant species strictly indicating that permafrost is present in the peat record, rapid changes in fossil peat assemblages from wet to dry habitat species can be used to infer permafrost inception (Oksanen et al. 2001; Oksanen 2006; Sannel \& Kuhry 2008). It has also been suggested that geochemical properties such as the carbon/nitrogen $(\mathrm{C} / \mathrm{N})$ ratio or the nitrogen content can be used to imply permafrost occurrence in northern peatlands (Vardy et al. 2000; Sannel \& Kuhry 2009; Treat et al. 2016).

Warmer conditions during recent decades have resulted in extensive permafrost degradation in Fennoscandian palsas and peat plateaus (Sollid \& Sørbel 1998; Zuidhoff \& Kolstrup 2000; Luoto \& Seppälä 2003; Sannel \& Kuhry 2011; Borge et al. 2017). At present the permafrost is close to thawing with mean annual ground temperatures just below $0{ }^{\circ} \mathrm{C}$ (Christiansen $\mathrm{et} \mathrm{al}$. 2010; Johansson et al. 2011; Sannel et al. 2016).

The aim of this study is to increase our understanding of Holocene peatland development and permafrost dynamics in subarctic peat plateaus and palsas in northernmost Sweden. This paper presents age-depth models, detailed palaeobotanical and geochemical data, and longterm carbon accumulation rates for six permafrost peatland sites. The timing of permafrost aggradation is derived from AMS radiocarbon dating of shifts in the macrofossil assemblage from fen vegetation dominated by sedges (Cyperaceae) and brown mosses (Amblystegieceae, Calliergonaceae and Meesiaceae) to dry bog vegetation characterized by Ericaceous shrubs and mosses of the genera Dicranum and Polytrichum. A better knowledge of Holocene permafrost and carbon dynamics in these ecosystems is important for understanding their long-term, as well as future, net radiative forcing potential.

\section{STUDY AREA}

Tavvavuoma is located in the sporadic permafrost zone in northernmost Sweden (Brown et al. 1997; Gisnås et al. 2017) (Fig. 1). It is one of the most extensive permafrost peatland areas in Sweden, but also in Fennoscandia (Wramner 1973; Ulfstedt 1982; Backe 2014; Gisnås et al. 2016). The underlying bedrock is of Precambrian origin, and the surrounding landscape is 
characterized by low mountains (up to $\sim 750 \mathrm{~m}$ a.s.1.) with a gentle relief (Ulfstedt 1982). Until around 10 300-10 200 cal. a BP the area was covered by the Fennoscandian Ice Sheet (Stroeven et al. 2016). The extensive peat plateau complex west of Lake Dávvajavri is underlain by glaciofluvial and lacustrine sediments, mostly sand, but also loam and gravel (Ivanova et al. 2011). Lakes, streams and wetlands are common, and the broad, flat valleys around $550 \mathrm{~m}$ a.s.l. are characterized by vast mires with both palsas and peat plateaus. Palsas are also found in surrounding high-plateau wetlands up to around $720 \mathrm{~m}$ a.s.l.

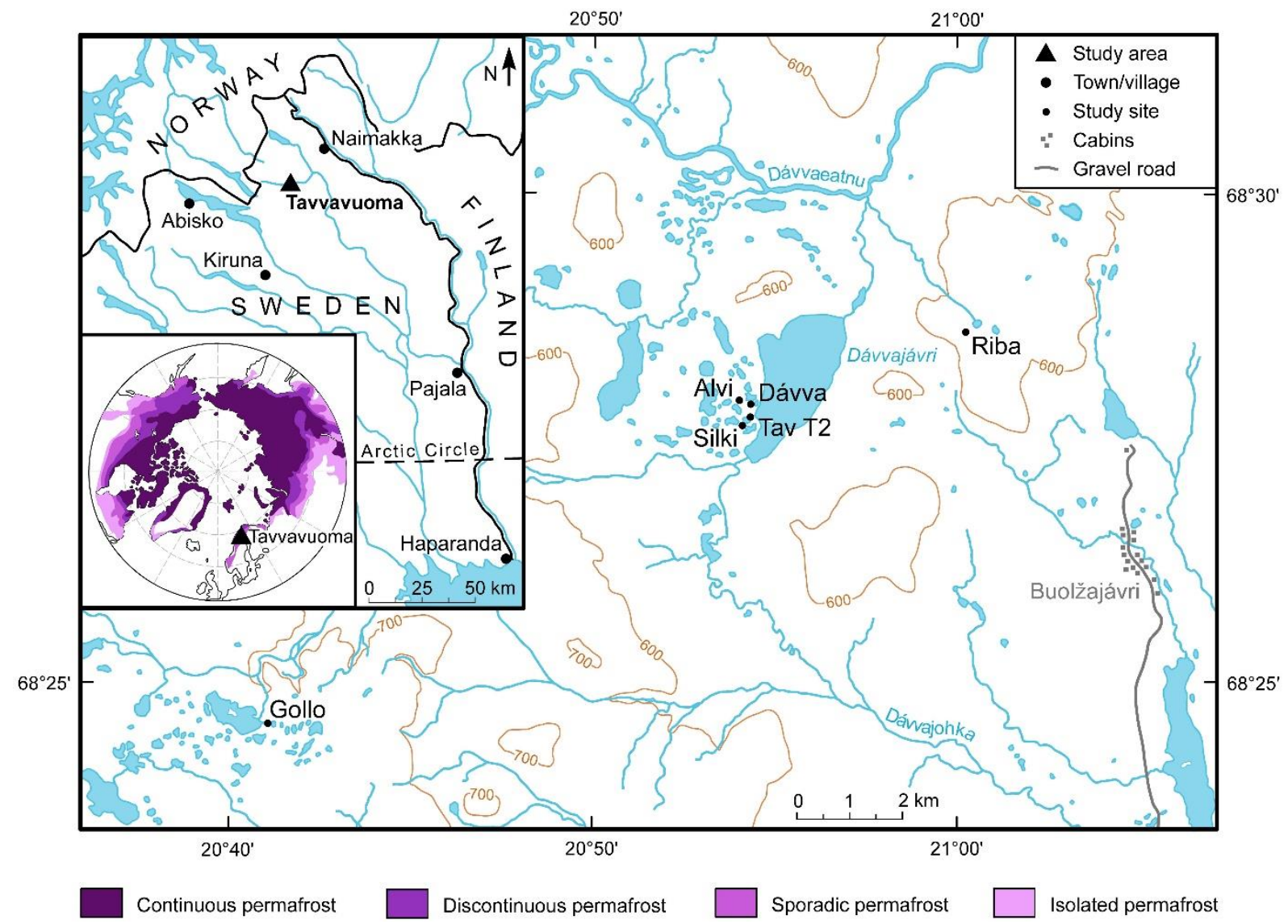

Fig. 1. Map showing the location of Tavvavuoma in northern Sweden, and the six study sites. Inset map with circum-arctic permafrost zonation adapted from Brown et al. (1997).

The study area is located in the ecotone between birch forest and tundra, and the forest limit in this region is found at around 550-600 $\mathrm{m}$ a.s.1. (Andersson et al. 1983). On mineral soils, patches of open mountain birch (Betula pubescens ssp. czerepanovii) forest are growing at lower elevation. At higher elevation dry heath is dominating, often with a dense cover of low growing B. nana. Along streams and lake shores dense stands of Salix spp. are found. On the peat plateaus and palsas the vegetation mainly consists of dwarf shrubs (Empetrum nigrum ssp. hermaphroditum, B. nana, Vaccinium uligunosum ssp. uligunosum, V. vitis-idaea, $V$. microcarpum, Andromeda polifolia), Rubus chamaemorus, lichens and mosses (Polytrichum juniperinum, Dicranum elongatum). In wind exposed areas deflated patches of bare peat occur. Cotton grasses (Eriophorum spp.), sedges (Carex spp.) and wet growing Sphagna are common in fens, water bodies encircling palsas and along lake margins. 
The mean annual air temperature (2006-2013) at the Tavvavuoma peat plateau ( 555 $\mathrm{m}$ a.s.1.) is $-2.1^{\circ} \mathrm{C}$. The mean temperature in July is $11.5^{\circ} \mathrm{C}$ and in January $-12.5^{\circ} \mathrm{C}$ (Sannel et al. 2016). The mean annual precipitation (2006-2013) is $461 \mathrm{~mm} \mathrm{a}^{-1}$ at the closest meteorological station in Naimakka $\left(68^{\circ} 41^{\prime} \mathrm{N}, 21^{\circ} 32^{\prime} \mathrm{E}, 402 \mathrm{~m}\right.$ a.s.1.) about $35 \mathrm{~km}$ northeast of the study area. The mean precipitation in the summer (June-September) is $245 \mathrm{~mm}$, and in the winter (November-April) $129 \mathrm{~mm}$ (Swedish Meteorological and Hydrological Institute http://opendata-catalog.smhi.se/explore/). The mean annual ground temperature in the peat plateau is currently warmer than $-0.3{ }^{\circ} \mathrm{C}$, and the active layer depth is around $55-60 \mathrm{~cm}$ (Sannel et al. 2016).

Peat profiles from six locations within the study area have been used for the analyses (Fig. 1). Four of the profiles were collected from peat plateaus in the approximately $2 \mathrm{~km}^{2}$ large peat plateau complex west of Lake Dávvajávri at around $555 \mathrm{~m}$ a.s.l.; Alvi $\left(68^{\circ} 27^{\prime} 51^{\prime \prime}\right.$ ' N,

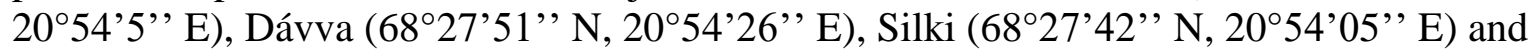
Tav T2 (68 $27^{\prime} 44^{\prime \prime}$ N, $20^{\circ} 54^{\prime} 08^{\prime \prime}$ E). The peat depth of the collected profiles was around 1-2 $\mathrm{m}$, which seems to be representative for these peat plateaus even though the thickness of the peat is rather variable despite the relatively flat surface (Sjöberg et al. 2015).

The remaining two profiles were collected from palsas, located in upland plateau wetlands. Gollo (68 $24^{\prime} 37^{\prime \prime}$ N, 20 $41^{\prime} 04^{\prime \prime}$ E) is a palsa site situated at about $715 \mathrm{~m}$ a.s.l., approximately $12 \mathrm{~km}$ southwest of Lake Dávvajávri. This site contains a few 1-2 m high palsas, and represents the uppermost presence of palsas in the Tavvavuoma area. The peat depth at the sampling site was $>2 \mathrm{~m}$. The Riba site $\left(68^{\circ} 28^{\prime} 38^{\prime \prime} \mathrm{N}, 21^{\circ} 0^{\prime} 11^{\prime \prime}\right.$ E) is located at about $615 \mathrm{~m}$ a.s.l., in an approximately $1 \mathrm{~km}^{2}$ large palsa mire complex with well-developed and up to $5 \mathrm{~m}$ high palsas, around $2 \mathrm{~km}$ east of Lake Dávvajávri. The ice-rich peat at the sampling site was $>2.3 \mathrm{~m}$ thick.

\section{METHODS}

\section{Field sampling}

The peat profiles were collected by hammering down a 1.2 or $2.2 \mathrm{~m}$ long and $4 \mathrm{~mm}$ thick steel pipe with an inner diameter of $30 \mathrm{~mm}$ into the ground $5-10 \mathrm{~cm}$ at a time before pulling it back up and carefully pressing out the sample with a steel rod (Fig. 2A, B). For Alvi $(185 \mathrm{~cm})$, Dávva $(105 \mathrm{~cm})$, Gollo $(207 \mathrm{~cm})$ and Riba $(230 \mathrm{~cm})$ the $10 \mathrm{~cm}$ segments were cut into subsamples representing $2.5 \mathrm{~cm}$ depth before they were put in ziploc bags. For Tav T2 (195 $\mathrm{cm})$ the $10 \mathrm{~cm}$ thick segments were not subsampled but brought back intact to the laboratory. At Silki $(208 \mathrm{~cm})$ the $5-10 \mathrm{~cm}$ segments were cut into $1 \mathrm{~cm}$ thick slices. Tav T2 was collected in September 2007, Silki in September 2009 and Alvi, Dávva, Gollo and Riba in August 2012. In August 2015 another sampling campaign was performed, where Alvi, Dávva, Gollo, Silki and Riba were re-visited and the peat in the active layer was resampled using a different technique where $12 \times 12 \times 55 \mathrm{~cm}$ large blocks were cut out, $<25 \mathrm{~cm}$ away from the original sampling holes, using a saw (Fig. 2C, D). To avoid disturbance of ongoing ground temperature monitoring at Tav T2 the active layer was not resampled at this site in 2015. All peat samples were kept frozen in the laboratory until analysed. 

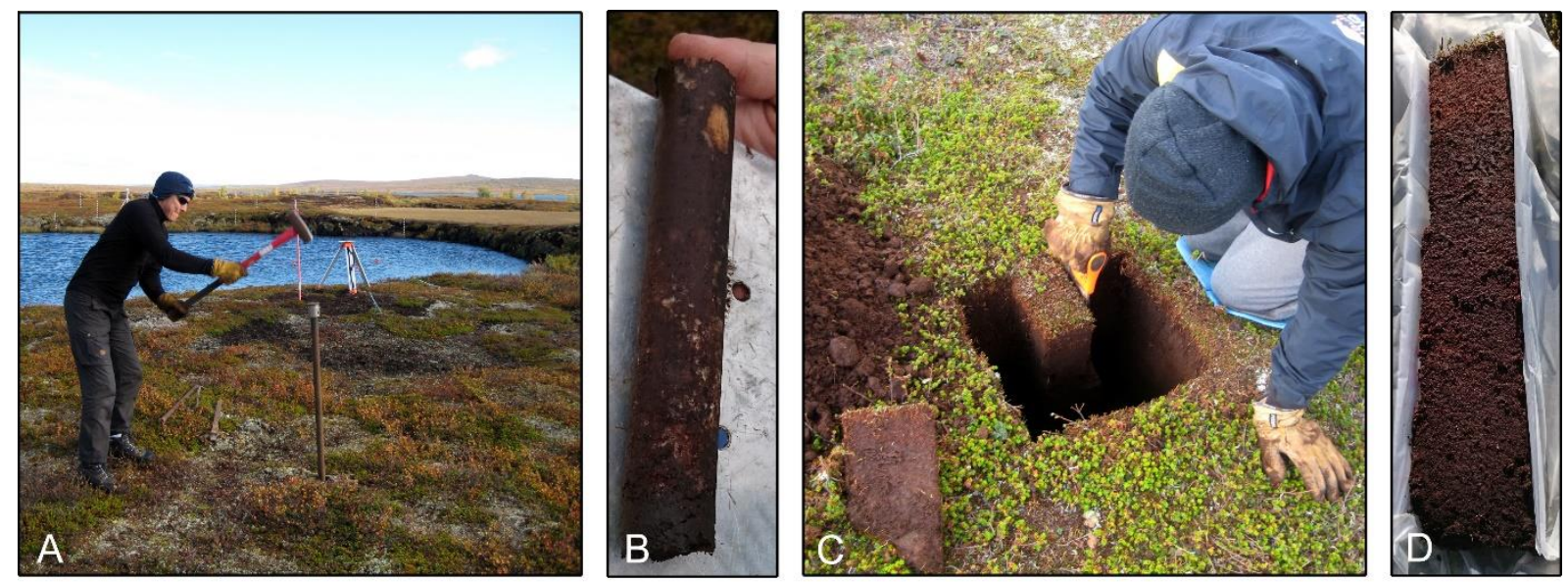

Fig. 2. Field sampling methods. Sampling with steel pipes $(A)$, and collected material $(B)$. Sampling using a saw $(C)$ to cut out blocks of peat $(D)$.

\section{Radiocarbon dating and age-depth models}

For each of the six peat profiles 6-7 samples were AMS radiocarbon dated. Where possible, terrestrial plant macrofossils were picked out for the analyses, as suggested by e.g. Kuhry \& Turunen (2006). In fen peat layers, where it was not possible to find enough terrestrial macrofossils or Sphagnum to date, bulk fen peat samples were submitted. According to an extensive circum-arctic study there is no bias when comparing radiocarbon dates of bulk peat with terrestrial macrofossil samples (Holmquist et al. 2016). To infer the timing of permafrost aggradation, organic material both above and below the contact between fen peat and xerophilic peat was dated, as proposed by Seppälä (2005). In a few cases when radiocarbon dates were suspected to be unreliably modern due to contamination with fresh plant material in the active layer during the steel pipe sampling (dates shown in Supporting Information, Table S1), supplementary samples were dated from the centre of the peat blocks that were sawed out in 2015 (see Field sampling). Radiocarbon dates were calibrated and age-depth models were constructed using the OxCal 4.2 programme (Bronk Ramsey 2009). BP refers to before AD 1950.

\section{Plant macrofossil analysis}

To determine the botanical composition of the peat profiles detailed plant macrofossil analyses were performed on 5-20 cm sampling intervals (5 cm intervals for Alvi, Dávva, Gollo and Riba, $10 \mathrm{~cm}$ intervals for Silki and $20 \mathrm{~cm}$ intervals for Tav T2). Samples of around $5 \mathrm{~cm}^{3}$ were analysed according to the methods described by Mauquoy \& Van Geel (2007).

For mosses, roots, epidermis, wood and bark the coverage was recorded as volume percentage of the total sample. For seeds, leaves and needles the numbers were counted and recalculated to a sample size of exactly $5 \mathrm{~cm}^{3}$. The nomenclature follows Laine et al. (2009) for Sphagnum, Hallingbäck et al. (2008) for Meesiaceae, Hedenäs et al. (2014) for Amblystegiaceae and Calliergonaceae, Nyholm $(1975,1979)$ for other mosses and Mossberg et al. (1992) for the vascular plants. The degree of decomposition was defined from 0 (almost intact mosses) to 5 (moss leaves fragmented by decomposition) according to moss preservation classes described by Janssens (1983). Macrofossil diagrams were plotted using C2, version 1.7.6 (Juggins 2014). 


\section{Geochemical analyses, carbon accumulation rates and storage}

Samples of approximately $5 \mathrm{~cm}^{3}$ were cut out at $5-20 \mathrm{~cm}$ intervals $(5 \mathrm{~cm}$ intervals for Dávva and Gollo, $10 \mathrm{~cm}$ intervals for Alvi, Riba and Silki and $20 \mathrm{~cm}$ intervals for Tav T2) for analyses of bulk density and organic matter content. Mostly, the same sample depths were used for these geochemical analyses as for the macrofossil analysis. Where there was not enough material available due to a high ice content in the peat, intermediate depths were used for the geochemical analyses (some depths for Dávva and Gollo). All samples were dried at 90-95 ${ }^{\circ} \mathrm{C}$ and weighed to calculate dry bulk densities, then burned at $550{ }^{\circ} \mathrm{C}$ for $2 \mathrm{~h}$ and weighed to determine the organic matter content. Some samples were also burned at $950{ }^{\circ} \mathrm{C}$ for $2 \mathrm{~h}$ to test if our samples contained carbonates (e.g. Heiri et al. 2001). Since the mass loss during burning at $950{ }^{\circ} \mathrm{C}$ was negligible, we ignored the inorganic carbon component in our further analyses.

To determine the organic carbon and nitrogen content, $<1 \mathrm{~cm}^{3}$ cubes of bulk peat were cut from all profiles at $10 \mathrm{~cm}$ intervals. The samples were freeze-dried, ground in an agate mortar and analysed for carbon and nitrogen content using a Carlo Erba Elemental Analyser NC2500. The relative error was $<1 \%$ for both measurements.

The apparent rate of carbon accumulation (net carbon accumulation) was determined for all six profiles by dividing the cumulative carbon mass (calculated using bulk density and carbon content for each analysed layer) between pairs of radiocarbon dates by the duration of the calibrated age interval. Median ages $(2 \sigma)$ were used for these calculations. When determining the total carbon storage, the cumulative carbon mass of peat layers also below the lowermost radiocarbon dated sample were included.

\section{RESULTS AND INTERPRETATION}

\section{Radiocarbon dating and age-depth models}

Radiocarbon dates for all six studied peat profiles are presented as ${ }^{14} \mathrm{C}$ age, calibrated age intervals and calibrated median ages in Table 1. For the most shallow peat profile, Dávva, the basal age was around $6000 \mathrm{cal}$. a BP. At the deepest peat deposit site, Riba, the mineral soil was not reached, but the peat at $2.3 \mathrm{~m}$ was dated to $c .8900 \mathrm{cal}$. a BP. All four other deep peat profiles had basal ages of around 10 000-9600 cal. a BP. The age-depth models follow a fairly similar pattern for all profiles, with generally higher peat accumulation rates in the early to mid-Holocene (until c. 6000-4000 cal. a BP) and slower accumulation in the late Holocene (Fig. 3). Particularly at Silki, but also at Alvi, the peat accumulation had almost ceased during the late Holocene (since around 3000 cal. a BP). 
Table 1. AMS radiocarbon dates from the six peat profiles.

\begin{tabular}{|c|c|c|c|c|c|c|}
\hline Site & Depth $(\mathrm{cm})$ & Lab no. & ${ }^{14} \mathrm{C}$ age (a BP) & Cal. a BP $(2 \sigma)$ & Median cal. a BP $(2 \sigma)$ & Material dated \\
\hline Alvi & $8.5-9.5$ & Vera-51641 & $317 \pm 55$ & $500-286$ & 387 & $\begin{array}{l}\text { Polytrichum juniperinum \& Betula } \\
\text { nana leaves }\end{array}$ \\
\hline Alvi & $14-16$ & Ua-55328 & $2578 \pm 31$ & $2762-2699,2633-2616,2587-2539,2526-2519$ & 2733 & Bulk fen peat (excluding dark roots) \\
\hline Alvi & $31-31.5$ & Vera-51642 & $3788 \pm 133$ & $4567-4559,4532-3827,3787-3778$ & 4178 & Bulk fen peat \\
\hline Alvi & $61-61.5$ & Vera-51643 & $4623 \pm 81$ & $5582-5507,5487-5212,5195-5049$ & 5353 & Bulk fen peat \\
\hline Alvi & $90-92.5$ & Poz-54388 & $6855 \pm 35$ & $7783-7775,7761-7613$ & 7683 & Bulk fen peat \\
\hline Alvi & $177.5-180$ & Poz-51846 & $8740 \pm 70$ & $10125-10063,10007-9993,9941-9543$ & 9738 & Leaves (B. nana) from fen peat \\
\hline Dávva & $3-4$ & Vera-51644 & $-267 \pm 62$ & $254-225,137-114,106-99,74-32$ & 54 & Dicranum elongatum \\
\hline Dávva & $6-7$ & Vera-51645 & $295 \pm 62$ & $503-271,187-150,12-$ & 373 & Twig from fen peat \\
\hline Dávva & $13-14$ & Ua-55329 & $1514 \pm 29$ & $1522-1456,1442-1432,1423-1335$ & 1395 & Bulk fen peat (excluding dark roots) \\
\hline Dávva & $30-32.5$ & Vera-51646 & $2519 \pm 95$ & $2766-2353$ & 2580 & Bulk fen peat \\
\hline Dávva & $56-56.5$ & Vera-51648 & $5101 \pm 49$ & $5939-5726$ & 5823 & Bulk fen peat \\
\hline Dávva & $82.5-85$ & Vera-51649 & $5189 \pm 86$ & $6188-5741$ & 5959 & Twig (Betula sp.) from fen peat \\
\hline Gollo & $6-7$ & Vera-51651 & $278 \pm 114$ & $511-241,233-60,41-$ & 316 & Leaves (B. nana) \\
\hline Gollo & $11-12$ & Ua-5530 & $466 \pm 28$ & $539-492$ & 514 & Bulk fen peat (excluding dark roots) \\
\hline Gollo & $51-51.5$ & Vera-51652 & $5511 \pm 62$ & $6435-6425,6415-6190$ & 6314 & Bulk fen peat \\
\hline Gollo & $100-102.5$ & Vera-51653 & $5710 \pm 82$ & $6671-6315$ & 6508 & Bulk fen peat \\
\hline Gollo & $150-152.5$ & Poz-54390 & $7630 \pm 50$ & $8541-8370$ & 8427 & Bulk fen peat \\
\hline Gollo & $200-202.5$ & Poz-51880 & $8670 \pm 50$ & 9771-9534 & 9623 & Bulk fen peat \\
\hline Riba & $8-9$ & Ua-55082 & $144 \pm 28$ & $282-241,233-169,153-60,41-4$ & 147 & Twigs (Betula sp.) \\
\hline Riba & $21-22$ & Vera-51640 & $2087 \pm 61$ & 2303-2241, 2180-1898 & 2062 & Twigs from fen peat \\
\hline Riba & $46-46.5$ & Vera-51647 & $5392 \pm 59$ & $6294-6093,6085-6002$ & 6194 & Bulk fen peat \\
\hline Riba & $70-72.5$ & Vera-51654 & $6318 \pm 69$ & $7420-7155,7113-7068,7057-7028$ & 7249 & Bulk fen peat \\
\hline Riba & 100-105 & Poz-54389 & $7000 \pm 40$ & $7935-7735$ & 7839 & Bulk fen peat \\
\hline Riba & $227.5-230$ & Poz-51881 & $8050 \pm 50$ & $9091-8746,8741-8725$ & 8927 & Bulk fen peat \\
\hline Silki & $6-7$ & Vera-51637 & $151 \pm 45$ & $285-165,158-57,44-$ & 151 & Leaves (B. nana) \\
\hline Silki & $9-10$ & Poz- 45368 & $3270 \pm 80$ & $3695-3345$ & 3504 & Bulk fen peat \\
\hline Silki & $37.6-38.4$ & Vera-51638 & $3945 \pm 42$ & $4519-4463,4451-4281,4275-4249$ & 4395 & Bulk fen peat \\
\hline Silki & $70-71$ & Poz-45369 & $4340 \pm 50$ & $\begin{array}{c}5042-4835 \\
6172-6157,6108-6081,6018-5891,5803-5795\end{array}$ & 4920 & Bulk fen peat \\
\hline Silki & $135-136$ & Poz-45370 & $5190 \pm 40$ & $5780-5773$ & 5948 & Bulk fen peat \\
\hline Silki & $172.8-173.6$ & Vera-51639 & $8899 \pm 70$ & $10207-9744$ & 10013 & Bulk fen peat \\
\hline Silki & $199.6-200.8$ & Poz-51858 & $8660 \pm 50$ & $9760-9755,9745-9532$ & 9615 & Bulk fen peat \\
\hline Tav T2 & $10-20$ & Poz-28721 & $115 \pm 35$ & $272-186,177-174,150-11$ & 119 & D. elongatum \\
\hline Tav T2 & $20-30$ & Ua-55331 & $1419 \pm 29$ & $1365-1290$ & 1321 & Bulk fen peat (excluding dark roots) \\
\hline Tav T2 & $62-65$ & Vera-51634 & $5864 \pm 44$ & $6787-6561$ & 6686 & Leaves (B. nana) from fen peat \\
\hline Tav T2 & $100-105$ & Vera-51635 & $6403 \pm 73$ & $7435-7174$ & 7334 & Leaves from fen peat \\
\hline Tav T2 & $160-165$ & Vera-51636 & $8103 \pm 92$ & $9302-8696,8675-8650$ & 9037 & Leaves from fen peat \\
\hline Tav T2 & 190-195 & Poz-28258 & $8860 \pm 50$ & $10173-9744$ & 9988 & Wood from fen peat \\
\hline
\end{tabular}



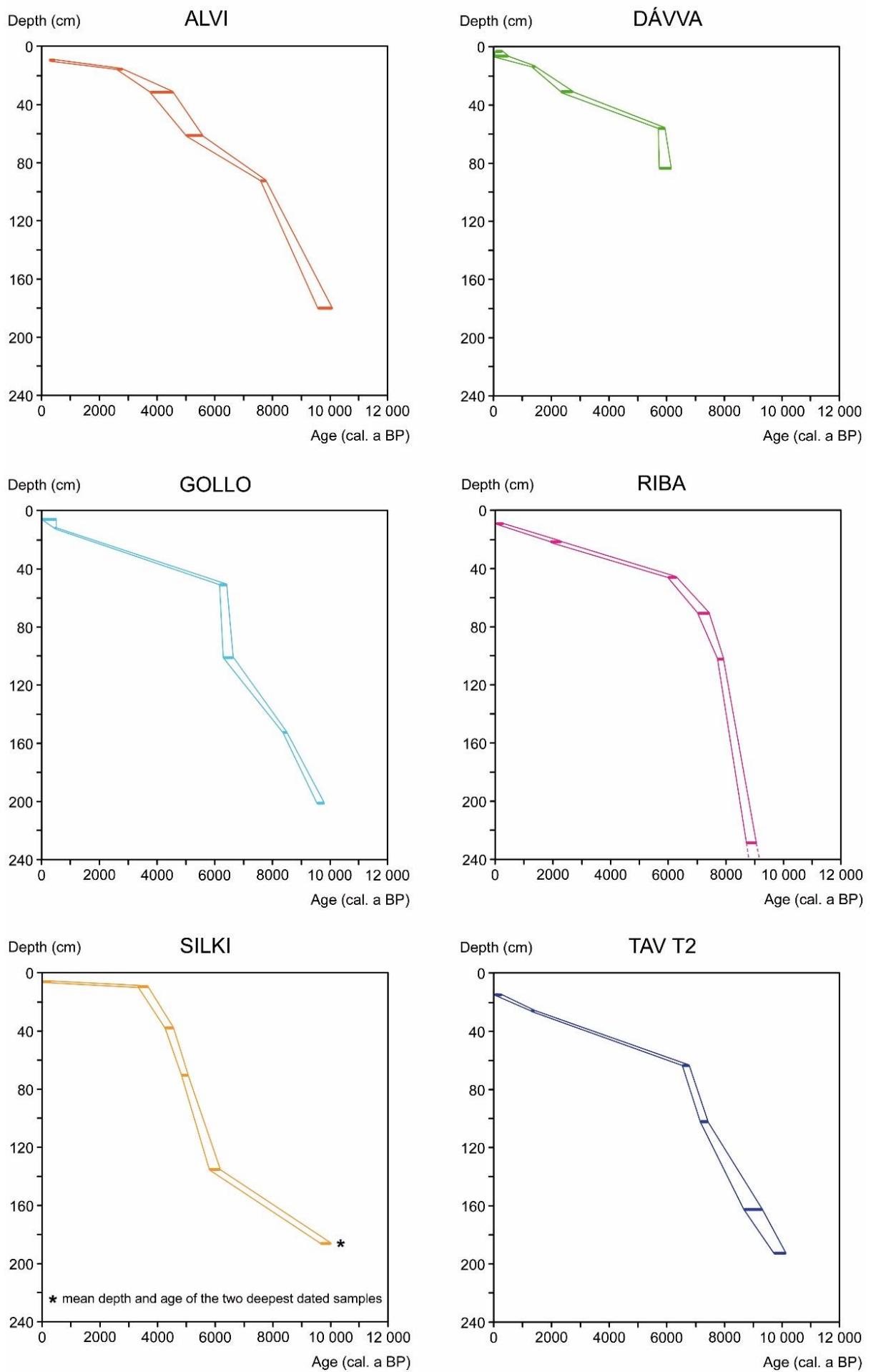

Fig. 3. Age-depth models for the six study sites. The horizontal lines represent calibrated age intervals $(2 \sigma)$.

\section{Plant macrofossil analysis}

Since all six peat plateau and palsa profiles displayed a similar successional behaviour, their plant macrofossil assemblages are not described separately in detail. For more comprehensive descriptions of the individual peat profiles the reader is referred to the macrofossil diagrams (Fig. 4). 
Zone 0 (>10 000-9600 cal. a BP). - In five of the profiles minerogenic sediments (mostly sand and silt) containing a low percentage of plant remains such as roots and mosses (e.g. Sarmentypnum exannulatum and Drepanocladus trifarius) were found at the base. The contact between the minerogenic soil and the overlying peat was usually found around $2 \mathrm{~m}$ depth. At Dávva the peat was more shallow $(<1 \mathrm{~m})$ and younger $(c .6000 \mathrm{cal}$. a BP), and at Riba the mineral soil below the peat was not reached at the maximum possible sampling depth of $2.3 \mathrm{~m}$ (dated c. $8900 \mathrm{cal}$. a BP).

Zone I (c. 10 000-9600 until c. 600-100 cal. a BP). - All studied peatlands started off as fens (at Riba, the basal peat was not reached but here the deepest collected peat layer is characterized by fen vegetation as well). In the early peatland stages brown mosses such as Paludella squarrosa, Meesia triquetra and Tomentypnum nitens were common, indicating a mineral and nutrient rich, wet fen environment. At three of the sites, Dávva, Gollo and Silki, Equisetum sp. was also occurring frequently. S. exannulatum and D. trifarius were very common and co-existed throughout this zone, often together with Scorpidium scorpoides and Calliergon spp. At most sites, epidermis and roots of herbaceuos plants were not very common in the initial fen stages, but became more frequent over time. Also, most profiles demonstrated a more or less distinct shift in the species composition of brown mosses with time. However, these changes in botanical composition do not have to imply a distinct alteration of the environment, as all found genera and species in this zone are suggesting wet and rich to intermediate fen conditions. Seeds of Carex spp. and Menyanthes trifoliata were also frequently recorded, and together with epidermis and roots of herbaceous plants (mainly Cyperaceae) also indicate fen conditions. Leaves and woody material, mainly from $B$. nana and Ericaceous shrubs, occurred in small quantities throughout zone I. These macrofossils suggest drier surface conditions, but since they were found in layers dominated by brown mosses and Cyperaceae it is likely that they have been transported to the sites by wind, streams or animals, and represent vegetation growing on drier hummocks in the peatland or on mineral soils in the nearby surroundings rather than being site specific. Wind or animal transport from neighbouring areas can also explain the occurrence of Picea abies needles around 9000 cal. a BP, only found at Tav T2. At sites where Sphagnum teres occurred, this moss species was mostly found in early stages of the peat sequence, but at Riba and Silki it also occurred in the upper fen peat layers implying relatively eutrophic conditions until the late Holocene. At the palsa site Gollo, S. lindbergii was frequently occurring during the entire fen stage, suggesting more oligotrophic, wet fen conditions. At most sites the uppermost fen peat was characterized by layers with a higher degree of decomposition, which could be associated with frost heave, exposing the top fen peat to environmental conditions suitable for aerobic decay.

Zone II (c. 600-100 cal. a BP until present). - This zone, comprising the uppermost 5-20 cm of the peat sequences, was characterized by a distinct shift in the vegetation from dominance by brown mosses and Cyperaceae, found below, to genera typical of drier environments. The macrofossil assemblage was dominated by roots, epidermis and leaves of Ericaceous shrubs, and mosses such as $D$. elongatum and $P$. juniperinum, all indicating relatively dry bog surface conditions. As the vegetation was similar to at the modern surface, this zone was interpreted to represent the peat plateau/palsa stage following permafrost aggradation and uplift by frost heave. 

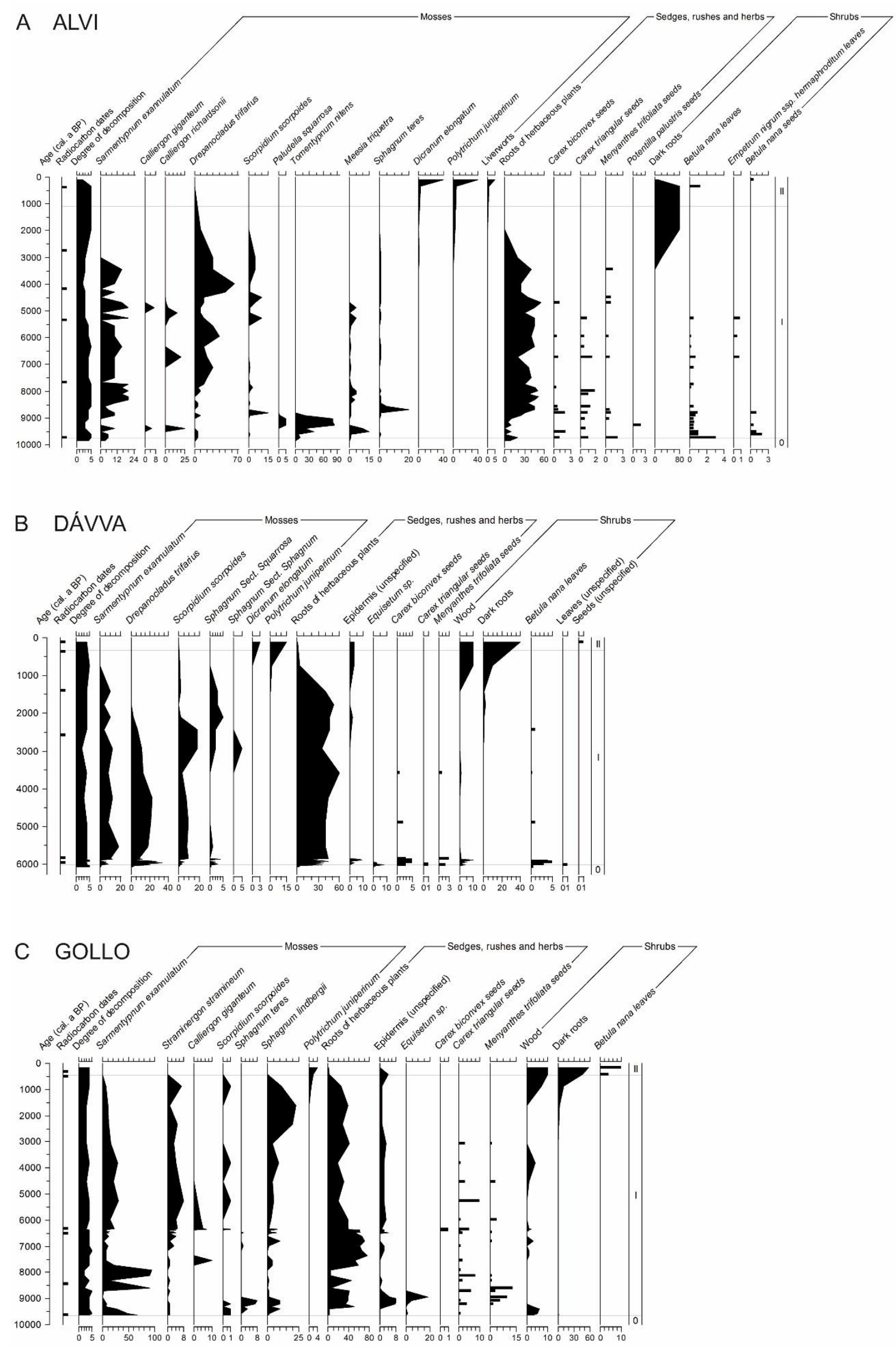

Fig. 4. Plant macrofossil diagrams for Alvi (A), Dávva (B), Gollo (C), Riba (D), Silki (E) and Tav T2 (F). Seeds and leaves are presented as units per $5 \mathrm{~cm}^{3}$. All other values are given in volume percentage. 

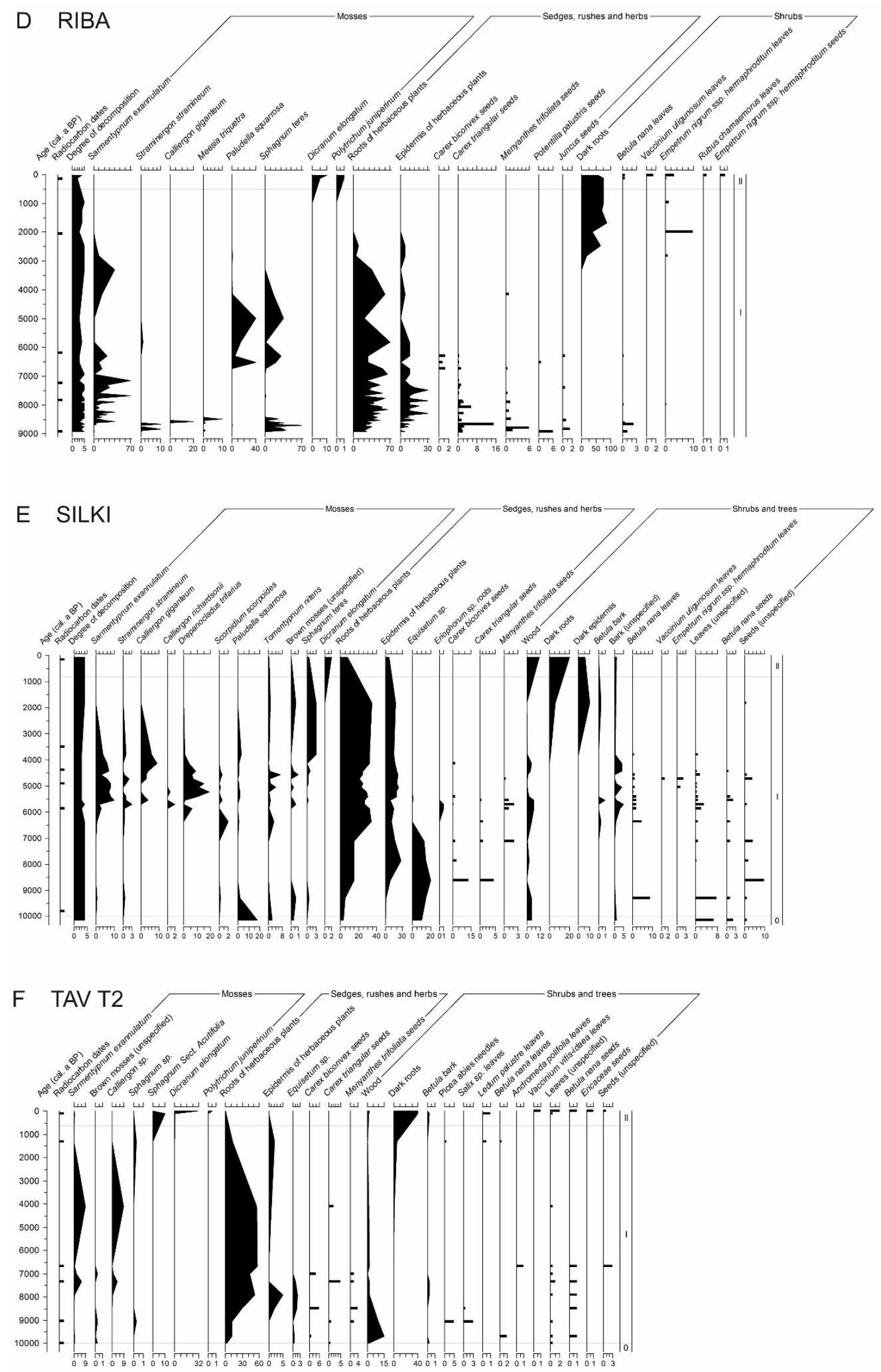

Fig. 4. Continued. 


\section{Geochemical analyses, carbon accumulation rates and storage}

The mean peat dry bulk density was $0.13 \pm 0.07 \mathrm{~g} \mathrm{~cm}^{-3}$ (standard deviation) at the six sites (0.02-0.36 $\mathrm{g} \mathrm{cm}^{-3)}$ (Fig. 5A). Higher bulk density values were recorded for layers with lower organic content, for example at Dávva during the mid-Holocene. These layers were characterized by a relatively high proportion of sand and finer inorganic material. Generally lower bulk densities were documented in strata below the active layer, due to a high ice content in the permafrost. For Alvi, Riba and Tav T2 the water content comprised 77-98\% of the wet weight in the permafrost peat samples.

Peat organic matter content was on average $90 \pm 12 \%$ for all six profiles (41-100\%). When excluding layers with a high proportion of inorganic sediments, the organic matter content was generally $>89 \%$. The mean carbon content was $49.4 \pm 5.9 \%$ (25.6-56.0\%) (Fig. 5B). The nitrogen content was on average $2.4 \pm 0.5 \%$ (1.1-3.2\%) (Fig. 5C). At Gollo and Silki the nitrogen content was relatively consistent throughout the peat profiles. At Alvi, Riba and Tav $\mathrm{T} 2$ the nitrogen content decreased in the upper permafrost bog peat.

The mean $\mathrm{C} / \mathrm{N}$ ratio was $21.7 \pm 5.5$ (11.1-43.2). At Alvi, Gollo and Silki the near basal peat layers had $\mathrm{C} / \mathrm{N}$ ratios that were nearly twice as high as further up in the profiles. These high $\mathrm{C} / \mathrm{N}$ ratios can be explained by a lower nitrogen content in these layers (Fig. 5D), possibly caused by differences in the botanical composition (distinct peaks in occurrence of T. nitens at Alvi, S. exannulatum at Gollo and P. squarrosa at Silki). At Alvi, Gollo, Riba and Tav T2 there was an increase in $\mathrm{C} / \mathrm{N}$ ratio in the uppermost permafrost bog peat layers (from $c$. 600$100 \mathrm{cal}$. a BP), compared to the fen peat below.

The carbon accumulation rates varied over time and between the study sites (Fig. 5E). Generally higher rates were recorded in the early to mid-Holocene, followed by lower accumulation rates in the late Holocene. Very low carbon accumulation rates $\left(<2 \mathrm{gC} \mathrm{m}^{-2} \mathrm{a}^{-1}\right)$ were reported for Silki from 3500-200 cal. a BP and for Alvi and Riba from around 27002100 cal. a BP until 400-100 cal. a BP.

The mean long-term net carbon accumulation rate at the study sites was $12.3 \pm 2.4 \mathrm{gC} \mathrm{m}^{-2} \mathrm{a}^{-1}$. The lowest value $\left(8.7 \mathrm{gC} \mathrm{m}^{-2} \mathrm{a}^{-1}\right)$ was recorded at the ice rich palsa site Riba, where the underlying mineral substrate was not reached. The highest carbon accumulation rate $(16.6 \mathrm{gC}$ $\mathrm{m}^{-2} \mathrm{a}^{-1}$ ) was reported from the other palsa site, Gollo. All four peat plateau sites had carbon accumulation rates between $10.2-13.6 \mathrm{gC} \mathrm{m}^{-2} \mathrm{a}^{-1}$ (Table 2).

The total carbon storage was on average $114 \pm 27 \mathrm{~kg} \mathrm{~m}^{-2}$. The carbon storage was $<100 \mathrm{~kg} \mathrm{~m}^{-2}$ at Dáava where the peat depth was relatively shallow $(95 \mathrm{~cm})$, but also at Riba $(230 \mathrm{~cm}$ peat depth) because of a very high ice content in the permafrost (Table 2). 

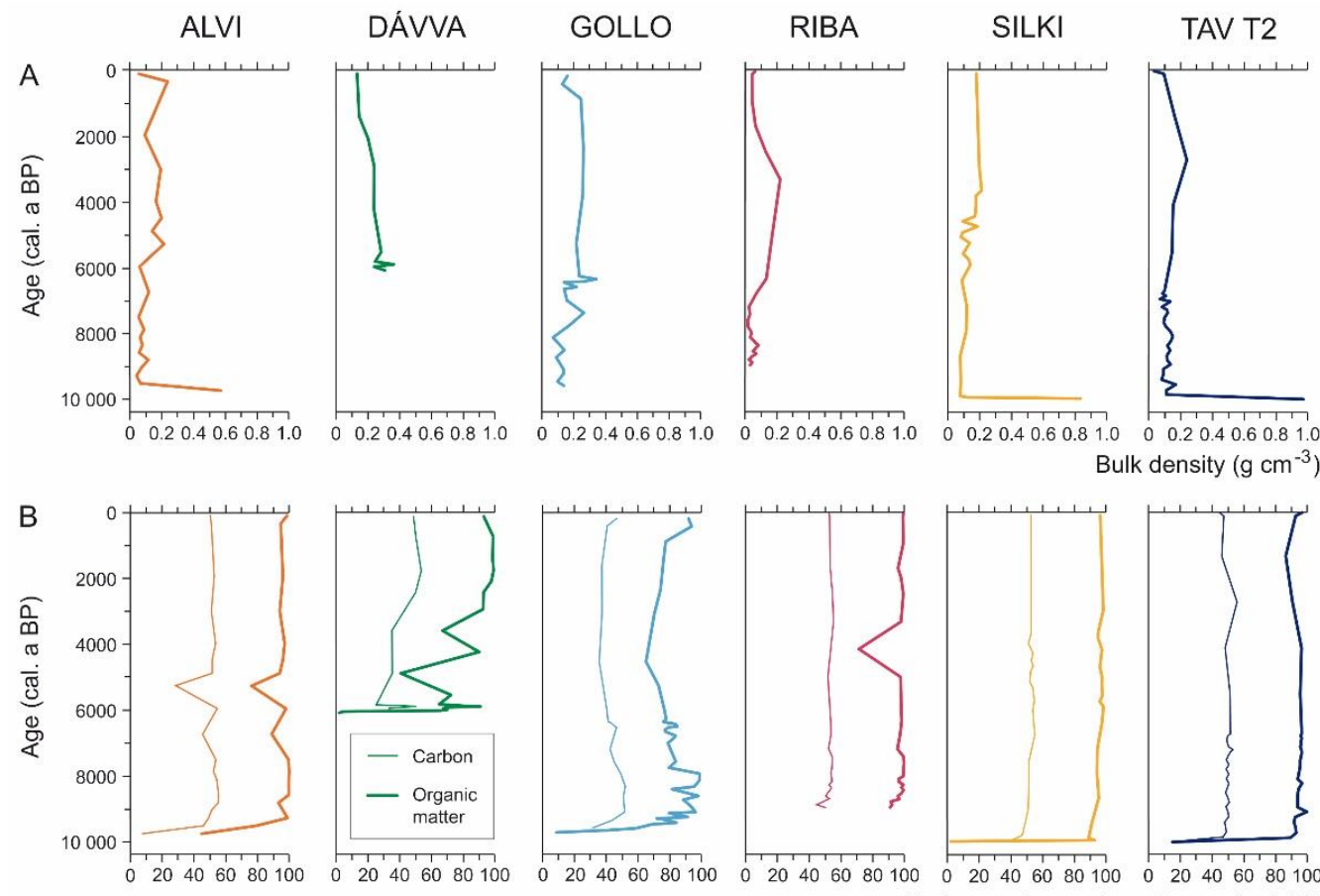

Carbon and organic matter content (\%)
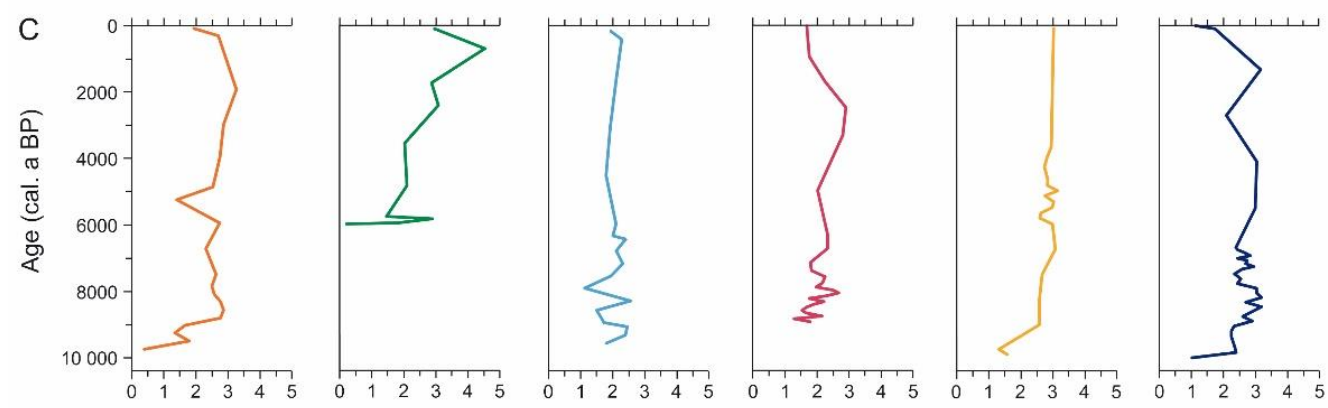

Nitrogen content (\%)
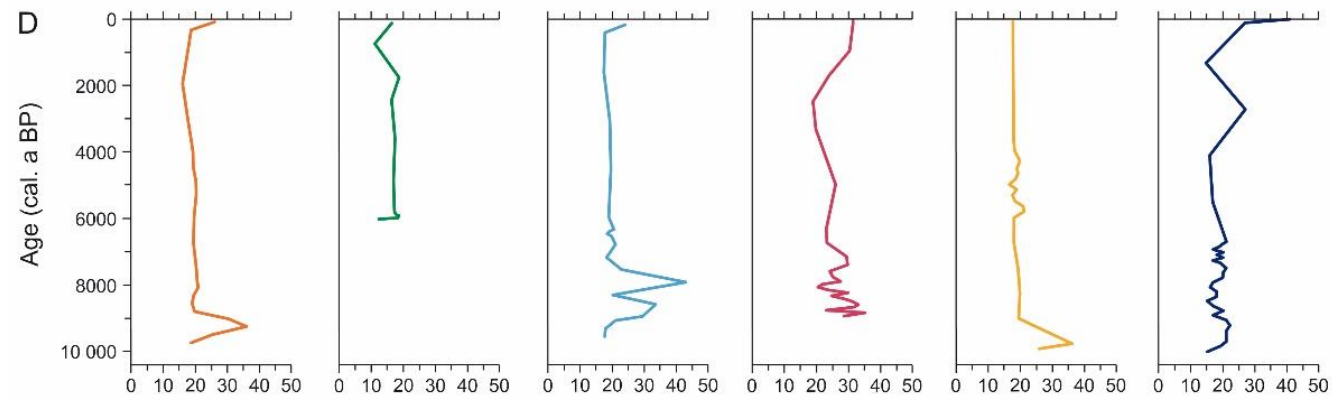

$\mathrm{C} / \mathrm{N}$ ratio
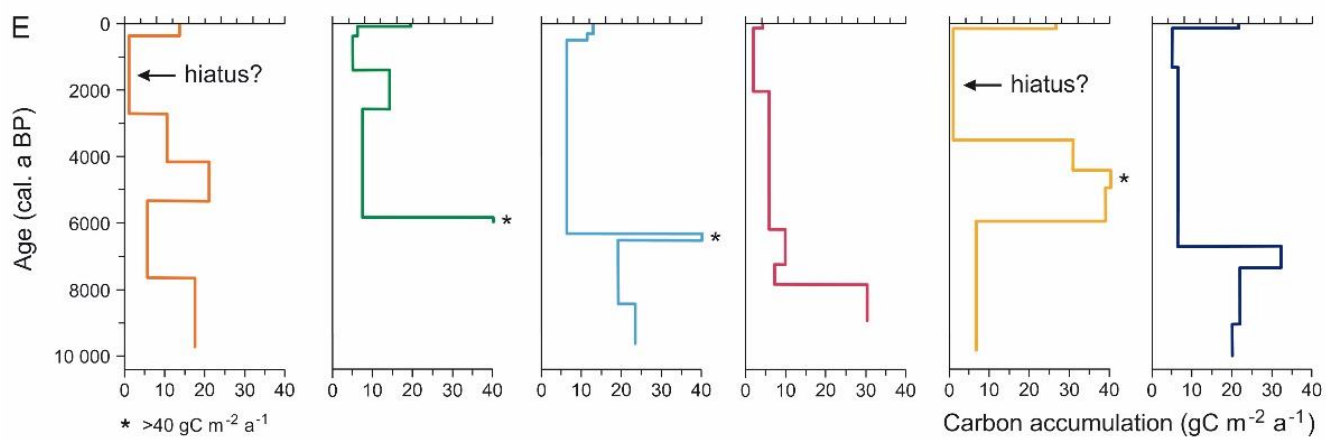

Fig. 5. Geochemical data; bulk density (A), carbon and organic matter content (B), nitrogen content $(C)$ and $C / N$ ratio $(D)$, and carbon accumulation rates $(E)$ at the six study sites. 
Table 2. Carbon storage and long-term net carbon accumulation rates at the peatland sites.

\begin{tabular}{lccccc}
\hline Site & $\begin{array}{c}\text { Total peat } \\
\text { depth }(\mathrm{cm})\end{array}$ & $\begin{array}{c}\text { Total carbon } \\
\text { storage }\left(\mathrm{kg} \mathrm{m}^{-2}\right)\end{array}$ & $\begin{array}{c}\text { Depth of } \\
\text { deepest dated } \\
\text { peat layer }(\mathrm{cm})\end{array}$ & $\begin{array}{c}\text { Median age }(2 \sigma) \text { of the } \\
\text { deepest dated peat } \\
\text { layer }(\mathrm{cal} . \mathrm{a} \mathrm{BP})\end{array}$ & $\begin{array}{c}\text { Net carbon } \\
\text { accumulation rate } \\
\left(\mathrm{gC} \mathrm{m}^{-2} \mathrm{a}^{-1}\right)\end{array}$ \\
\hline Alvi & 179 & 100.3 & 179 & 9738 & 10.2 \\
Dávva & 95 & 92.8 & 84 & 5959 & 13.5 \\
Gollo & 207 & 160.8 & 201 & 9623 & 16.6 \\
Riba & $>230$ & $>77.8$ & 229 & 8927 & 8.7 \\
Silki & 203 & 131.1 & $187^{1}$ & $9814^{1}$ & 12.7 \\
Tav T2 & 192 & 121.8 & 192 & 9988 & 12.1 \\
\hline
\end{tabular}

${ }^{1}$ Mean of the two lowermost dated peat layers.

\section{DISCUSSION}

\section{Peatland inception}

In northern Fennoscandia extensive peatland initiation began around 10000 cal. a BP, soon after deglaciation of the Fennoscandian Ice Sheet (e.g. Korhola et al. 2010; Weckström et al. 2010; Ruppel et al. 2013). According to Stroeven et al. (2016) Tavvavuoma became ice free around 10 300-10 $200 \mathrm{cal}$. a BP. Our study shows that peatlands started to form in the lowlands west of Lake Dávvajávri ( 555 m a.s.l.) around 10000 cal. a BP (at Silki and Tav T2, c. 400 years later at Alvi). At the palsa site Gollo, located further southwest at $\sim 715 \mathrm{~m}$ a.s.l., peatland initiation took place around $9700 \mathrm{cal}$. a BP. In the early peatland stages the plant macrofossils consisted of brown mosses (e.g. S. exannulatum and P. squarrosa), Equisetum sp. and seeds of Carex spp. and M. trifoliata typically found in wet, rich fen environments. Since there are no indications in the macrofossil records of local vegetation growing on dry mineral soil or plants growing in lake environments we conclude that peat formation must have begun on wet, bare mineral soils soon after deglaciation. Primary mire formation is therefore suggested as the main initiation pathway for these peatlands. At the other palsa site Riba ( $\sim 615 \mathrm{~m}$ a.s.1.) the mineral soil below the peat was not reached during the sampling. Hence it is difficult to say when and how this peatland formed. As the botanical composition of the peat layers from around 8900 cal. a BP (the deepest dated peat layer) and onwards is similar to the other four sites with older basal dates, it is likely that the peatland at Riba formed through primary mire formation approximately at the same time as the other sites. During peatland initiation (c. 10 000-9600 cal. a BP) the climatic conditions in the region were favourable for plant productivity with around $3{ }^{\circ} \mathrm{C}$ warmer summer temperatures compared to today (Kullman \& Öberg 2015), resulting in relatively rapid peat and net carbon accumulation rates during the early Holocene.

At Dávva, located closer to the present peatland margin and Lake Dávvajávri in the east, the basal peat is several thousand years younger, and formed around $6000 \mathrm{cal}$. a BP. There are no plant macrofossils in the basal peat or in the underlying substrate suggesting that there has been a lake or previously vegetated dry mineral soils at the site prior to peatland inception. But because of the long time since deglaciation, it is unlikely that this peatland formed through primary mire formation on bare soil. A more probable initiation pathway is lateral peatland expansion through paludification. However, terrestrialization along the shoreline of 
the very shallow Lake Dávvajávri is also possible, even though the macrofossil record does not support that.

\section{Peatland development}

All studied peatlands in Tavvavuoma have remained wet, permafrost-free fens during most of the Holocene. The plant macrofossil records showed a fairly consistent occurrence of brown mosses and remains of herbaceous plants (mainly Cyperaceae) throughout most of the profiles. Rather stable, and low $\mathrm{C} / \mathrm{N}$ ratios throughout the Holocene also support the interpretation from the macrofossil record of a relatively homogenous wet fen environment under permafrost-free conditions. Even where there were distinct shifts in the species composition of brown mosses, the changes do not imply a rapid modification of the environmental conditions. Through the Holocene there has generally been a slow transition from nutrient and mineral rich wet fens in the early stages to rich to intermediate wet fens in the later stages. Needles of $P$. abies found at the site Tav T2 at 160-165 cm depth were dated to around $9000 \mathrm{cal}$. a BP, and support the statement by Kullman $(2001,2008)$ and Öberg \& Kullman (2011) that $P$. abies was present in the Swedish Scandes already during the early Holocene, several thousand years earlier than inferred from pollen data. Warmer conditions during the Holocene Thermal Maximum, with $2.5-1.5^{\circ} \mathrm{C}$ higher temperatures in the Nordic region from 9000-4000 cal. a BP (Birks \& Seppä 2010), have not resulted in drier fen surfaces in Tavvavuoma. Contrary, the increased temperatures most likely triggered the relatively high peat and net carbon accumulation rates recorded during this time interval. Lower accumulation rates in the studied peatlands since around 6000-4000 cal. a BP can at least partly be explained by a cooler and moister climate during the Neoglacial period (e.g. Seppä \& Birks 2001).

\section{Permafrost development and dynamics}

Previous studies are mainly suggesting permafrost aggradation in northern Fennoscandian peatlands around 700-100 cal. a BP (Vorren 1979; Malmer \& Wallén 1996; Zuidhoff \& Kolstrup 2000; Oksanen 2006; Kokfelt et al. 2010). However, two of these studies also suggest an earlier period of permafrost inception around 2600-2500 cal. a BP (Oksanen 2006; Kokfelt et al. 2010). At the northern Finnish site, permafrost is expected to have prevailed since initiated (Oksanen 2006), whereas the northern Swedish site shows signs of considerable peat loss around $2100 \mathrm{cal}$. a BP as a result of thermokarst or wind abrasion (Kokfelt et al. 2010). Seppälä (2005) concludes that most palsas in Finnish Lapland are younger than 1000 years. When dating organic material just above and below the contact between xerophilic and fen peat, he found that sometimes there is a rather substantial time gap between these layers, probably due to wind abrasion. Also Malmer \& Wallén (1996) report old peat ages (around 7000-3000 cal. a BP) at rather shallow depths $(40-70 \mathrm{~cm})$, further supporting the idea that erosion can occur prior to, or during, permafrost aggradation. Our study showed very low peat and carbon accumulation during the late Holocene from around 3500-2700 cal. a BP until around 400-100 cal. a BP in two of the profiles (Alvi and Silki) (Fig. 5E). At Silki only $30 \mathrm{~mm}$ of peat accumulated during a time period of $>3200$ years (Fig. 3). This suggests occurrence of hiatuses, possibly caused by abrasion during or after uplift by frost heave associated with permafrost inception. At these sites it is therefore difficult to conclude exactly when permafrost first developed. At the other four sites, radiocarbon dates from the uppermost fen peat layer and lowermost permafrost bog peat layer imply that the peat accumulation has been continuous. At all these sites the datings together with the results of the plant macrofossil analyses suggest that permafrost aggradation took place around 600 100 cal. a BP. 


\section{Carbon and nitrogen content, $\mathrm{C} / \mathrm{N}$ ratio and carbon accumulation rates}

The peat carbon content is partly controlled by the species composition, and therefore differs between different vegetation types (Mäkilä 1997; Treat et al. 2016). For northern circumpolar peatlands the bulk carbon content is normally 42-47\% (Treat et al. 2016). From Finnish Lapland Mäkilä \& Moisanen (2007) report an average carbon content of 52\%. In Tavvavuoma the mean carbon content was $49 \%$. The relatively low carbon, nitrogen and organic matter content at Alvi and Dávva around 6000-4500 cal. a BP could be caused by local deposition of fine minerogenic material that has been transported by winds from esker or dune surfaces in the surrounding landscape. Given that the end of the Holocene Thermal Maximum (HTM) is characterized by high temperatures and low humidity (Seppä et al. 2009), it is plausible that vegetation growing on sandy, well-drained soils declined during this period, leaving the soil bare.

The botanical composition also affects the nitrogen content of the peat (Bergner et al. 1990; Treat et al. 2016). From northern Sweden, average nitrogen values of 2.5-3.0\% are reported for sedge and brown moss/sedge peat (Bergner et al. 1990). In Tavvavuoma, where the profiles were dominated by fen peat deposited in non-permafrost environments, the mean nitrogen content was $2.4 \%$. Furthermore, permafrost aggradation can have an impact on the nitrogen content by inhibiting decomposition below the active layer. For high-latitude northern peatlands Treat et al. (2016) report average nitrogen values of 1.3-1.8\% for brown moss and herbaceous peat. In peats with similar botanical composition the nitrogen content is lower in permafrost environments, suggesting that a low nitrogen content can be used as a proxy for permafrost conditions (Treat et al. 2016).

In Tavvavuoma the mean $\mathrm{C} / \mathrm{N}$ ratio was $21.7 \pm 5.5$. This fits well with average values of $18-22$ reported for sedge and brown moss/sedge peat from northern Sweden (Bergner et al. 1990), but is lower than the average of 29 recorded for fen peat at high northern latitudes (Treat et al. 2016). Because of limited decay under permafrost conditions, high $\mathrm{C} / \mathrm{N}$ ratios have been suggested as a proxy of permafrost presence in peatlands (Vardy et al. 2000; Sannel \& Kuhry 2009; Treat et al. 2016). The low $\mathrm{C} / \mathrm{N}$ ratios in our study further validate the interpretation of the macrofossil record, that permafrost has not been present in the studied peatlands throughout most of the Holocene. The increase in $\mathrm{C} / \mathrm{N}$ in the uppermost layers at Alvi, Gollo, Riba and Tav T2 supports the interpretation of LIA permafrost aggradation, even though the $\mathrm{C} / \mathrm{N}$ ratios are still relatively low (around 25-40) in the upper peat layers as decay can still take place in the active layer. Higher $\mathrm{C} / \mathrm{N}$ ratios in the top layers could also be a result of the shift in botanical composition, or the relatively short time available for organic matter decay since permafrost inception.

The median long-term net carbon accumulation rate in circumpolar boreal peatlands is $14 \mathrm{gC}$ $\mathrm{m}^{-2} \mathrm{a}^{-1}$. Slightly higher rates are reported for permafrost-free bogs $\left(18 \mathrm{gC} \mathrm{m}^{-2} \mathrm{a}^{-1}\right)$ and fens $(23$ $\mathrm{gC} \mathrm{m}^{-2} \mathrm{a}^{-1}$ ) (Treat et al. 2016). In northern Swedish and Finnish mires the carbon accumulation rates are 12-16 $\mathrm{gC} \mathrm{m}^{-2} \mathrm{a}^{-1}$ (Klarqvist et al. 2001; Oksanen, 2006; Mäkilä \& Moisanen, 2007). Our study reports a mean carbon accumulation rate of $12.3 \pm 2.4 \mathrm{gC} \mathrm{m}^{-2} \mathrm{a}^{-1}$ for all six profiles (averages ranging from 8.7-16.6 $\mathrm{gC} \mathrm{m}^{-2} \mathrm{a}^{-1}$ ), with generally higher carbon accumulation rates in the early to mid-Holocene (until around 6000-4000 cal. a BP) and lower rates during the late Holocene. This fits well with the overall decrease in carbon accumulation rates in circumpolar peatlands, particularly during the Neoglacial period (after 5000 cal. a BP), when permafrost begins to develop (Loisel et al. 2014). The very high carbon accumulation rates $\left(>40 \mathrm{gC} \mathrm{m}^{-2} \mathrm{a}^{-1}\right)$ reported from Dávva and Gollo during the mid-Holocene (Fig. 5E) are unrealistically high and probably caused by uncertainties in the radiocarbon 
dating of the peat. The very low carbon accumulation rates $\left(<1.5 \mathrm{gC} \mathrm{m}^{-2} \mathrm{a}^{-1}\right)$ at Alvi from 2700-400 cal. a BP and at Silki from 3500-200 cal. a BP are most likely caused by hiatuses in the peat sequences, as suggested by the very slow peat accumulation rates in the age-depth models (Fig. 3). Alternatively, the low accumulation rates during this time period could be caused by dry conditions, decreasing the bog surface wetness and productivity (Seppä et al. 2009). Also at Riba the carbon accumulation rate is relatively low (c. $\left.2 \mathrm{gC} \mathrm{m}^{-2} \mathrm{a}^{-1}\right)$ from 2100-100 cal. a BP, but at this site the drop in accumulation rate is less distinct and therefore not necessarily implying a hiatus, as the carbon accumulation rate has been continuously low $\left(<6 \mathrm{gC} \mathrm{m}^{-2} \mathrm{a}^{-1}\right)$ from the mid-Holocene until present.

\section{Implications for the land-atmosphere carbon balance}

Through uptake of $\mathrm{CO}_{2}$ by photosynthesis and accumulation of organic matter, the studied peatlands have acted as long-term net carbon sinks during the Holocene. However, because of the prevailing wet fen conditions causing anaerobic decay environments, relatively high emissions of mainly $\mathrm{CH}_{4}$ can be expected to have occurred, as subarctic fens generally produce high $\mathrm{CH}_{4}$ fluxes (Olefeldt et al. 2013). In the late Holocene the peatlands at Alvi and Silki can temporarily have turned into net carbon sources as abrasion probably took place. Since permafrost aggradation during the LIA all studied peat plateau and palsa surfaces have acted as net carbon sinks, with carbon accumulation rates between $4-27 \mathrm{gC} \mathrm{m}^{-2} \mathrm{a}^{-1}$. Relatively low emissions of greenhouse gases, mainly $\mathrm{CO}_{2}$, are expected from these dry surfaces (e.g. Svensson et al. 1999; Olefeldt et al. 2013). In a future warmer climate thermokarst processes are expected to cause shifts in the landscape from dry permafrost bogs into wet fens or lakes (e.g. Schuur et al. 2008; Schuur et al. 2015). This would further accelerate the permafrost degradation, and at least in the short term increase greenhouse gas emissions from these ecosystems through decomposition of previously frozen soil organic matter.

\section{CONCLUSIONS}

At the studied peat plateau and palsa sites in northern Sweden:

- Peatland development began through primary mire formation $c .10$ 000-9600 cal. a BP, soon after deglaciation of the Fennoscandian Ice Sheet.

- The peatlands have remained permafrost-free fens throughout most of the Holocene.

- The transition from fen to dry bog conditions following permafrost inception took place $c .600-100$ cal. a BP.

- There are no clear indications of permafrost aggradation prior to the Little Ice Age, even though plausible hiatuses at two of the sites complicate the interpretation.

- The mean long-term Holocene net carbon accumulation rate was $12.3 \pm 2.4 \mathrm{gC} \mathrm{m}^{-2} \mathrm{a}^{-1}$ and the mean soil organic carbon storage was $114 \pm 27 \mathrm{~kg} \mathrm{~m}^{-2}$.

- Despite acting as Holocene net carbon sinks, emissions of mainly $\mathrm{CH}_{4}$ have likely been high during extended periods of wet fen conditions, and can become extensive again in the future if thermokarst becomes more widespread 


\section{ACKNOWLEDGEMENTS}

Britta Sannel received financial support for field work, radiocarbon dating and geochemical analyses from the Swedish Society for Anthropology and Geography (SSAG), the Bolin Centre for Climate Research and the Swedish Research Council for Environment, Agricultural Sciences and Spatial Planning (214-2014-562). Two anonymous reviewers provided valuable comments that improved the manuscript. We would also like to thank $\mathrm{Mr}$ Jesper Sannel for assistance during field sampling of the profile Silki, Prof. Peter Kuhry and Dr Gustaf Hugelius (Stockholm University) for field sampling of the profile Tav T2, Ms Sara Lundqvist (Stockholm University) for geochemical analyses of Tav T2, Ms Heike Siegmund (Stockholm University) for performing the $\mathrm{C} / \mathrm{N}$ analysis and Dr Lars Hedenäs (the Swedish Museum of Natural History) for valuable assistance with identification of mosses.

\section{REFERENCES}

Andersson, L., Rafstedt, T. \& Von Sydow, U. 1983: Vegetationskarta över de svenska fjällen - Kartblad nr 1 Treriksrröset/Naimakka. Scale 1:100 000. Fjällens vegetation kartor. Meddelande från Naturgeografiska institutionen, Stockholms universitet 165.

Backe, S. 2014: Kartering av Sveriges palsmyrar. Länsstyrelsens rapportserie 4/2014, 54 pp.

Birks, H. J. B. \& Seppä, H. 2010: Late-Quaternary paleoclimatic research in Fennoscandia - a historical review. Boreas 39, 655-673.

Bergner, K., Bohlin, E. \& Albano, Å. 1990: Vad Innehåller Torv? A Compilation of Botanical, Physical and Chemical Data of Peat. 54 pp. Sveriges Lantbruksuniversitet, Umeå.

Bjune, A. E., Seppä, H. \& Birks, H. J. B. 2009: Quantitative summer-temperature reconstructions for the last 2000 years based on pollen-stratigraphical data from northern Fennoscandia. Journal of Paleolimnology 41, 43-56.

Borge, A. F., Westermann, S., Solheim, I. \& Etzelmüller, B. 2017: Strong degradation of palsas and peat plateaus in northern Norway during the last 60 years. The Cryosphere 11, 116.

Bronk Ramsey, C. 2009: Bayesian analysis of radiocarbon dates. Radiocarbon 51, 337-360.

Brown, J., Ferrians, O. J. Jr, Heginbottom, J. A. \& Melinkov, E. S. 1997: Circum-arctic map of permafrost and ground ice conditions. Scale 1:10,000,000. U.S. Geological Survey, Washington, D.C.

Christiansen, H. H., Etzelmüller, B., Isaksen, K., Juliussen, H., Humlum, O., Johansson, M., Ingeman-Nielsen, T., Kristensen, L., Hjort, J., Holmlund, P., Sannel, A. B. K., Sigsgaard, C., Åkerman, H. J., Foged, N., Blikra, L. \& Ødegaard, M. 2010: The thermal state of permafrost in the Nordic area during the International Polar Year 2007-2009. Permafrost and Periglacial Processes 21, 156-181.

Collins, M., Knutti, R., Arblaster, J., Dufresne, J.-L., Fichefet, T., Friedlingstein, P., Gao, X., Gutowski, W. J., Johns, T., Krinner, G., Shongwe, M., Tebaldi, C., Weaver, A. J. \& Wehner, M. 2013: Long-term climate change: Projections, commitments and irreversibility. In Stocker, T. F, Qin, D., Plattner, G.-K., Tignor, M., Allen, S. K., Boschung, J., Nauels, A., Xia, Y., Bex, V. \& Midgley, P. M. (eds.): Climate change 2013: The physical science basis. Contribution of Working Group I to the Fifth Assessment Report of the Intergovernmental Panel on Climate Change, 1031-1136. Cambridge University Press, Cambridge.

Frolking, S. \& Roulet, N. T. 2007: Holocene radiative forcing impact of northern peatland carbon accumulation and methane emissions. Global Change Biology 13, 1079-1088. 
Gisnås K., Etzelmüller, B., Lussana, C., Hjort, J., Sannel, A. B. K., Isaksen, K., Westermann, S., Kuhry, P., Christiansen, H. H., Frampton, A. \& Åkerman, J. 2017: Permafrost map for Norway, Sweden and Finland. Permafrost and Periglacial Processes 28, 359-378.

Gorham, E. 1991: Northern peatlands: Role in the carbon-cycle and probable responses to climatic warming. Ecological Applications 1, 182-195.

Grudd, H., Briffa, K. R., Karlén, W., Bartholin, T. S., Jones, P. D. \& Kromer, B. 2002: A 740-year tree-ring chronology in northern Swedish Lapland: natural climatic variability expressed on annual to millennial timescales. The Holocene 13, 657-665.

Hallingbäck, T., Lönnell, N., Weibull, H., Von Knorring, P., Korotynska, M., Reisborg, C. \& Birgersson, M. 2008: Nationalnyckeln till Sveriges Flora och Fauna. Bladmossor:

Kompaktmossor-kapmossor. Bryophyta: Anoectangium-Orthodontium. 504 pp.

ArtDatabanken, SLU, Uppsala.

Hedenäs, L., Reisborg, C. \& Hallingbäck, T. 2014: Nationalnyckeln till Sveriges Flora och Fauna. Bladmossor: Skirmossor-baronmossor. Bryophyta: Hookeria-Anomodon. 366 pp. ArtDatabanken, SLU, Uppsala.

Heiri, O., Lotter, A. F. \& Lemcke, G. 2001: Loss on ignition as a method for estimating organic and carbonate content in sediments: reproducibility and comparability of results. Journal of Paleolimnology 25, 101-110.

Holmquist, J. R., Finkelstein, S. A., Garneau, M., Massa, C., Yu, Z. \& MacDonald, G. M. 2016: A comparison of radiocarbon ages derived from bulk peat and selected plant macrofossils in basal peat cores from circum-arctic peatlands. Quaternary Geochronology 31, 53-61.

Hugelius, G., Strauss, J., Zubrzycki, S., Harden, J., Schuur, E. A. G., Ping, C.-L., Schirrmeister, L., Grosse, G., Michaelson, G., Koven, C., O’Donnell, J., Elberling, B., Mishra, U., Camill, P., Yu, Z., Palmtag, J. \& Kuhry P. 2014: Estimated stocks of circumpolar permafrost carbon with quantified uncertainty ranges and identified data gaps. Biogeosciences $11,6573-6593$.

Ivanova, N. V., Kuznetsova, I. L., Parmuzin, I. S., Rivkin, F. M., \& Sorokovikov, V. A. 2011: Geocryological conditions in Swedish Lapland. In Proceedings of the 4th Russian Conference on Geocryology, 7-9 June 2011, Moscow State University, 77-82, Moscow, Russia.

Janssens, J. A. 1983: A quantitative method for stratigraphic analysis of Bryophytes in Holocene peat. Journal of Ecology 71, 189-196.

Johansson, M., Åkerman, J., Keuper, F., Christensen T. R., Lantuit, H. \& Callaghan, T. V. 2011: Past and present permafrost temperatures in the Abisko area: redrilling of boreholes. Ambio 40, 558-565.

Juggins, S. 2014: C2 Version 1.7.6. Software for ecological and paleoecological data analysis and visualisation. Newcastle University, UK.

Klarqvist, M., Bolin, E. \& Nilsson, M. 2001: Long-term decline in apparent peat accumulation in boreal mires in northern Sweden. In Klarqvist, M. (ed.): Peat growth and carbon accumulation rates during the Holocene in boreal mires, 1-22. Acta Universitatis Agriculturae Sueciae, Silvestria 203.

Kokfelt, U., Reuss, N., Struyf, E., Sonesson, M., Rundgren, M., Skog, G., Rosén, P. \& Hammarlund, D. 2010: Wetland development, permafrost history and nutrient cycling inferred from late Holocene peat and lake sediment records in subarctic Sweden. Journal of Paleolimnology 44, 327-342. 
Korhola, A., Ruppel, M, Seppä, H., Väliranta, M., Virtanen, T. \& Weckström, J. 2010: The importance of northern peatland expansion to the late-Holocene rise of atmospheric methane. Quaternary Science Reviews 29, 611-617.

Kuhry, P. \& Turunen, J. 2006: The postglacial development of boreal and subarctic peatlands. In Wieder R. K. \& Vitt D. H. (eds.): Boreal Peatland Ecosystems, 25-46. Springer, Berlin Heidelberg.

Kullman, L. 2001: Immigration of Picea abies into North-Central Sweden. New evidence of regional expansion and tree-limit evolution. Nordic Journal of Botany 21, 39-54.

Kullman, L. 2008: Early postglacial appearance of tree species in northern Scandinavia: review and perspective. Quaternary Science Reviews 27, 2467-2472.

Kullman, L. \& Öberg, L. 2015: New aspects of high-mountain palaeobiogeography: a synthesis of data from forefields of receding glaciers and ice patches in the Tärna and Kebnekaise mountains, Swedish Lapland. Arctic 68, 141-152.

Laine, J., Harju, P., Timonen, T., Laine, A., Tuittila, E.-S., Minkkinen, K. \& Vasander, H. 2009: The Intricate Beauty of Sphagnum Mosses - a Finnish Guide to Identification. 190 pp. University of Helsinki Department of Forest Ecology Publications 39.

Loisel, J., Yu, Z., Beilman, D. W., Camill, P., Alm, J., Amesbury, M. J., Anderson, D., Andersson, S., Bochicchio, C., Barber, K., Belyea, L. R., Bunbury, J., Chambers, F. M., Charman, D. J., De Vleeschouwer, F., Fiałkiewicz-Kozieł, B., Finkelstein, S. A., Gałka, M., Garneau, M., Hammarlund, D., Hinchcliffe, W., Holmquist, J., Hughes, P., Jones, M. C., Klein, E. S., Kokfelt, U., Korhola, A., Kuhry, P., Lamarre, A., Lamentowicz, M., Large, M., Lavoi, M., MacDonald, G., Magnan, G., Makila, M., Mallon, G., Mathijssen, P., Mauquoy, D., McCarroll, J., Moore, T. R., Nichols, J., O’Reilly, B., Oksanen, P., Packalen, M., Peteet, D., Richard, P. J. H., Robinson, S., Ronkainen, T., Rundgren, M., Sannel, A. B. K., Tarnocai, C., Thom, T., Tuittila, E.-S., Turetsky, M., Väliranta, M., Van der Linden, M., Van Geel, B., Van Bellen, S., Vitt, D., Zhao, Y. \& Zhou, W. 2014: A database and synthesis of northern peatland soil properties and Holocene carbon and nitrogen accumulation. The Holocene 24, $1028-1042$.

Luoto, M. \& Seppälä, M. 2003: Thermokarst ponds as indicators of the former distribution of palsas in Finnish Lapland. Permafrost and Periglacial Processes 14, 19-27.

MacDonald,G. M., Beilman, D. W., Kremenetski, K. V., Sheng, Y., Smith, L. C. \& Velichko, A. A. 2006: Rapid early development of circumarctic peatlands and atmospheric $\mathrm{CH}_{4}$ and $\mathrm{CO}_{2}$ variations. Science 314, 285-288.

Mäkilä, M. 1997: Holocene lateral expansion, peat growth and carbon accumulation on Haukkasuo, a raised bog in southeastern Finland. Boreas 26, 1-14.

Mäkilä, M. \& Moisanen, M. 2007: Holocene lateral expansion and carbon accumulation of Luovuoma, a northern fen in Finnish Lapland. Boreas 36, 198-210.

Malmer, N. \& Wallén, B. 1996: Peat formation and mass balance in subarctic ombrotrophic peatlands around Abisko, northern Scandinavia. Ecological Bulletins 45, 79-92.

Mauquoy, D. \& Van Geel, B. 2007: Mire and peat macros. In Birks, H. H. (ed.): Plant Macrofossils - Articles from the Encyclopedia of Quaternary Science, 2315-2336. Elsevier, Amsterdam.

Mossberg, B., Stenberg, L. \& Ericsson, S. 1992: Den Nordiska Floran. 696 pp. Wahlström \& Widstrand, Belgium. 
Nyholm, E. 1975: Illustrated Moss Flora of Fennoscandia II. Musci, Fasc. 1. 1-84. Swedish Natural Science Research Council, Gotab, Kungälv.

Nyholm, E. 1979: Illustrated Moss Flora of Fennoscandia II. Musci, Fasc. 6. 647-799. Swedish Natural Science Research Council, Gotab, Kungälv.

Öberg, L. \& Kullman, L. 2011: Ancient subalpine clonal spruces (Picea abies): sources of postglacial vegetation history in the Swedish Scandes. Arctic 64, 183-196.

Oksanen, P. O., Kuhry, P. \& Alekseeva, R. N. 2001: Holocene development of the Rogovaya River peat plateau, European Russian Arctic. The Holocene 11, 25-40.

Oksanen, P. O. 2006: Holocene development of the Vaisjeäggi palsa mire, Finnish Lapland. Boreas 35, 81-95.

Olefeldt, D., Turetsky, M. T., Crill, P. M. \& McGuire, A. D. 2013: Environmental and physical controls on northern terrestrial methane emissions across permafrost zones. Global Change Biology 19, 589-603.

Parviainen, M. \& Luoto, M. 2007: Climate envelopes of mire complex types in Fennoscandia. Geografiska Annaler 89A, 137-151.

Ruppel, M. M., Väliranta, M., Virtanen, T. \& Korhola, A. 2013: Postglacial spatiotemporal peatland initiation and lateral expansion dynamics in North America and northern Europe. The Holocene 23, 1596-1606.

Sannel, A. B. K. \& Kuhry, P. 2008: Long-term stability of permafrost in subarctic peat plateaus, west-central Canada. The Holocene 18, 589-601.

Sannel, A. B. K. \& Kuhry, P. 2009: Holocene peat growth and decay dynamics in sub-arctic peat plateaus, west-central Canada. Boreas 38, 13-24.

Sannel, A. B. K. \& Kuhry P. 2011: Warming-induced destabilization of peat plateau/thermokarst lake complexes. Journal of Geophysical Research - Biogeosciences 116, doi:10.1029/2010JG001635.

Sannel, A. B. K., Hugelius, G., Jansson, P. \& Kuhry, P. 2016: Permafrost warming in a subarctic peatland - which meteorological controls are most important? Permafrost and Periglacial Processes 17, 177-188.

Schuur, E. A. G., Bockheim, J., Canadell, J. G., Euskirchen, E., Field, C. B., Goryachkin, S. V., Hagemann, S., Kuhry, P., Lafleur, P. M., Lee, H., Mazhitova, G., Nelson, F. E., Rinke, A., Romanovsky, V. E., Shiklomanov, N., Tarnocai, C., Venevsky, S., Vogel, J. G., Zimov, S. A. 2008: Vulnerability of permafrost carbon to climate change: implications for the global carbon cycle. BioScience 58, 701-714.

Schuur, E. A. G., McGuire, A. D., Schädel, C., Grosse, G., Harden, J. W., Hayes, D. J., Hugelius, G., Koven, C. D., Kuhry, P., Lawrence, D. M., Natali, S. M., Olefeldt, D., Romanovsky, V. E., Schaefer, K., Turetsky, M. R., Treat, C. C. \& Vonk, J. E. 2015: Climate change and the permafrost carbon feedback. Nature 520, 171-179.

Seppä, H \& Birks, H. J. B. 2001: July mean temperature and annual precipitation trends during the Holocene in the Fennoscandian tree-line area: pollen based climate reconstructions. The Holocene 11, 527-537.

Seppä, H., Bjune, A. E., Telford, R. J., Birks, H. J. B. \& Veski, S. 2009: Last nine-thousand years of temperature variability in Northern Europe. Climate of the Past 5, 523-535. 
Seppälä, M. 2005: Dating of palsas. In Ojala, A. E. K. (ed.): Quaternary studies in the northern and Arctic regions of Finland, 79-84. Geological Survey of Finland, Special Paper 40.

Sjöberg, Y., Coon, E., Sannel, A. B. K., Pannetier, R., Harp, D., Frampton, A., Painter, S. L. \& Lyon, S. W. 2016: Thermal effects of groundwater flow through subarctic fens - a case study based on field observations and numerical modeling. Water Resources Research 52, 1591-1606.

Sollid, J. L. \& Sørbel, L. 1998: Palsa bogs as a climate indicator - examples from Dovrefjell, southern Norway. Ambio 27, 287-291.

Stroeven, A. P., Hättestrand, C., Kleman, J., Heyman, J., Fabel, D., Fredin, O., Goodfellow, B. W., Harbor, J. M., Jansen, J. D., Olsen, L., Caffee, M. W., Fink, D., Lundqvist, J., Rosqvist, G. C., Strömberg, B. \& Jansson, K. N. 2016: Deglaciation of Fennoscandia. Quaternary Science Reviews 147, 91-121.

Svensson, B. H., Christensen, T. R., Johansson, E. \& Öquist, M. 1999. Interdecadal changes in $\mathrm{CO}_{2}$ and $\mathrm{CH}_{4}$ fluxes of a subarctic mire: Stordalen revisited after 20 years. Oikos 85, 22-30.

Tarnocai, C. 2006: The effect of climate change on carbon in Canadian peatlands. Global and Planetary Change 53, 222-232.

Tarnocai, C., Canadell, J. G., Schuur, E. A. G., Kuhry, P., Mazhitova, G. \& Zimov, S. A. 2009: Soil organic carbon pools in the northern circumpolar permafrost region. Global Biogeochemical Cycles 23, doi:10.1029/2008GB003327.

Treat, C. C., Jones, M. C., Camill, P., Gallego-Sala, A., Garneau, M., Klein, E. S., Kokfelt, U., Kuhry, P., Loisel, J., Mathijssen, P. J. H., O’Donnell, J. A., Oksanen, P. O., Ronkainen, T. M., Sannel, A. B. K., Talbot, J., Tarnocai, C. \& Väliranta, M. 2016: Effects of permafrost aggradation on peat properties as determined from a pan-Arctic synthesis of plant macrofossils. Journal of Geophysical Research - Biogeosciences 121, 78-94.

Ulfstedt, A.-C. 1982: Geomorphological maps 32 J Treriksröset 32 K Kummavuopio 31 J Rastojaure 31 K Naimakka - Description and assessment of areas of geomorphological importance. 61 pp. Rapport snv pm 1555, Naturvårdsverket.

Vardy, S. R., Warner, B. G., Turunen, J. \& Aravena, R. 2000: Carbon accumulation in permafrost peatlands in the Northwest Territories and Nunavut, Canada. The Holocene 10, 273-280.

Vorren, K.-D. 1979: Recent palsa datings, a brief survey. Norsk Geografisk Tidsskrift 33, $217-220$.

Weckström, J., Seppä, H. \& Korhola, A. 2010: Climatic influence on peatland formation and lateral expansion in sub-arctic Fennoscandia. Boreas 39, 761-769.

Wramner, P. 1973: Studies of Palsa Bogs in Taavavuoma and the Laiva Valley, Swedish Lapland. 285 pp. Department of Physical Geography, University of Göteborg.

Yu, Z. C., Beilman, D. W. \& Jones, M. C. 2009: Sensitivity of northern peatland carbon dynamics to Holocene climate change. In Baird, A. J., Belyea, L. R., Comas, X., Reeve, A. S. \& Slater, L. D. (eds.): Carbon cycling in northern peatlands. Geophysical Monograph Series $184,55-69$.

Yu, Z., Loisel, J., Brosseau, D. P., Beilman, D. W. \& Hunt, S. J. 2010: Global peatland dynamics since the Last Glacial Maximum. Geophysical Research Letters 37, doi:10.1029/2010GL043584. 
Yu, Z. 2011: Holocene carbon flux histories of the world's peatlands: global carbon-cycle implications. The Holocene 21, 761-774.

Zuidhoff, F. S. \& Kolstrup, E. 2000: Changes in palsa distribution in relation to climate change in Laivadalen, northern Sweden, especially 1960-1997. Permafrost and Periglacial Processes 11, 55-69. 